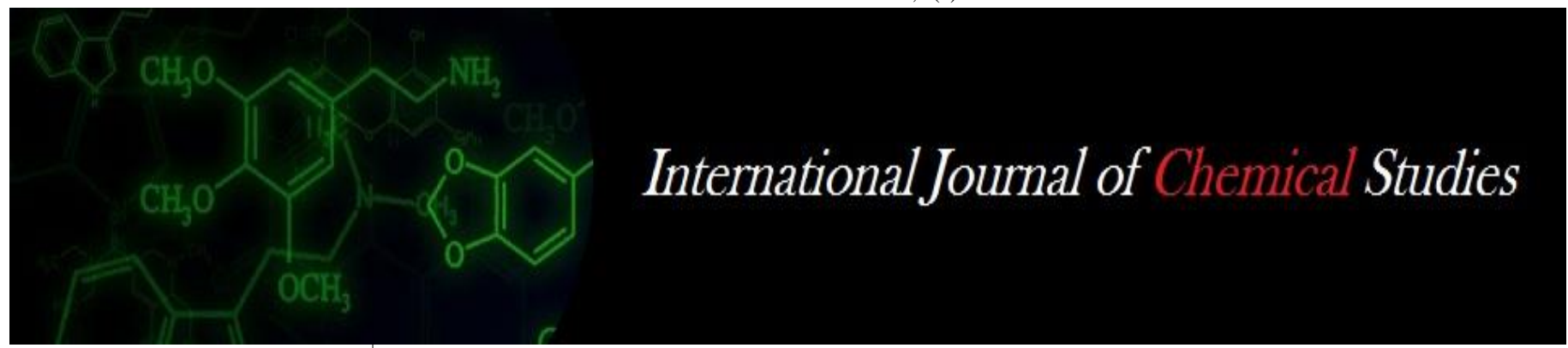

P-ISSN: 2349-8528

E-ISSN: 2321-4902

www.chemijournal.com

IJCS 2020; 8(1): 2844-2847

(C) 2020 IJCS

Received: 19-11-2019

Accepted: 21-12-2019

Abhijeet Satpathy

Ph.D. Scholar, Department of

Extension Education, College of Agriculture, Odisha University

of Agriculture and Technology,

Bhubaneswar, Odisha, India

Sasanka Lenka

Ph.D. Scholar, Department of

Extension Education, College of

Agriculture, Odisha University

of Agriculture and Technology,

Bhubaneswar, Odisha, India
Corresponding Author: Abhijeet Satpathy Ph.D. Scholar, Department of Extension Education, College of Agriculture, Odisha University of Agriculture and Technology, Bhubaneswar, Odisha, India

\section{Socio-economic attributes and information source consultancy pattern of vegetable growers in East Singhbhum district of Jharkhand}

\author{
Abhijeet Satpathy and Sasanka Lenka
}

DOI: https://doi.org/10.22271/chemi.2020.v8.i1aq.8700

\begin{abstract}
The study was conducted purposively in East Singhbhum district of Jharkhand with a view to analyse the socio-economic attributes of vegetable growers and to determine their marketing behavior. The sample size covered 120 vegetable growers from 10 villages \& response was obtained from each individual respondent with the help of a structured interview schedule pretested with 10 percent samples other than the respondents of the study. The findings of the study revealed that majority of the vegetable growers were middle-aged (59.1\%) and 32.5 percent had primary school education. The majorities $(42.5 \%)$ of respondents were having small land holding size, $(83.3 \%)$ respondents were involved in solely vegetable cultivation, majorities $(47.5 \%)$ have a medium level of farming experience, and 46.7 percent of the respondents had no membership in any organization. The detailed study of information source consultancy pattern showed that in mass media sources T.V. occupied the highest mean scores of 2.616 and ranked $1^{\text {st }}$ in the sources of information use. 44.33 percent and 70.83 percent of the respondents had medium risk-bearing ability and a medium level of innovativeness.
\end{abstract}

Keywords: Socio-economic, information source, marketing behavior, innovativeness

\section{Introduction}

Vegetables play an important role in nutritional security, economic viability and fit well into the predominant intensive cropping systems prevailing in different parts of our country. More than 60 kinds of vegetables are grown in India in tropical, subtropical and temperate agroclimates. India is the largest producer of okra and ranks 2 nd in the production of potato, onion, cauliflower, and cabbage. During 2013-2014, India produced 162.19 million tonnes of vegetables and vegetable export from our country was worth Rs. 5462.93 crores. For a balanced diet, an adult who works moderately needs about 300 grams of vegetables per day, of which about 50 grams should comprise of root vegetables, 50 grams of leafy vegetables and 200 grams of other kinds of vegetables as per Dietary Guidelines for Indians, NIN, 2011.

The vegetable is one of the important crops of Jharkhand, which is being cultivated on a commercial scale. About $3.2 \%$ of the gross cropped area of the State is devoted to the vegetable crops. Vegetable development depends not only on production but also on marketing system. Vegetable cultivation being labour intensive, can substantially increase employment avenues too.

The vegetable marketing problems in rural areas have not been studied in a systematic way even though numbers of studies have been conducted in the country. Presently, development of marketing infrastructure to solve the problems of vegetable growers in rural areas is the primary concern of the government. Intensified efforts are needed to identify the specific problems related to vegetable marketing. Keeping this in view, the present investigation was undertaken with the following

\section{Objectives}

Specific objectives of the study:

1. To study the socio-economic attributes of vegetable growers in the study area.

2. To determine the information source consultancy pattern of vegetable growers. 


\section{Materials and Methods}

In this study, Ex-post-facto research design was used. This design is appropriate because the phenomenon has already occurred. The state of Jharkhand was selected purposively because it has immense potential for the marketing of agricultural produce and establishment of the local market, Hatt / weekly market etc. East Singhbhum district was selected purposively for the study. This district contributes a major share to the vegetable production of Jharkhand. The study was conducted in Mosaboni, Ghatshila, Baharagora, Dumaria, Patamda Blocks of East Singhbhum district of Jharkhand. Both purposive and random sampling techniques were followed in the study. The districts and blocks selected purposively, whereas the villages were selected randomly and from ten villages 120 respondents were selected through disproportionate random sampling method. The primary data were collected through personal interview method with the help of pre-tested interview schedule, which was prepared on the basis of objectives of investigation and variables. The interview schedule was thoroughly discussed with the member of the advisory committee and their suggestions were incorporated. The statistical tests and procedures were used for analyzing the data with the help of statistical tools likemean, S.D., percentage were used for the analysis of data.

\section{Results and Discussion}

Socio-Economic profile of vegetable growers

Table 1: Socio- Economic profile of vegetable growers

\begin{tabular}{|c|c|c|c|c|c|c|}
\hline Sl. No. & Traits & Category & Frequency & Percentage & Mean & SD \\
\hline \multirow{3}{*}{1.} & \multirow{3}{*}{ Age } & Young (below 35 years) & 23 & 19.2 & \multirow[b]{3}{*}{47.01} & \multirow[b]{3}{*}{11.38} \\
\hline & & Middle aged (35-55 years) & 71 & 59.1 & & \\
\hline & & Old (Above 55 years) & 26 & 21.7 & & \\
\hline \multirow{6}{*}{2.} & Education & Illiterate & 28 & 23.3 & \multirow[b]{6}{*}{2.77} & \multirow[b]{6}{*}{1.45} \\
\hline & & Can read \& write & 21 & 17.5 & & \\
\hline & & Primary school & 39 & 32.5 & & \\
\hline & & Middle school & 14 & 11.7 & & \\
\hline & & High school & 11 & 9.2 & & \\
\hline & & College \& above & 7 & 5.8 & & \\
\hline \multirow{2}{*}{3.} & \multirow{2}{*}{ Family Type } & Nuclear & 46 & 38.3 & \multirow[b]{2}{*}{1.61} & \multirow[b]{2}{*}{0.48} \\
\hline & & Joint & 74 & 61.7 & & \\
\hline \multirow{3}{*}{4.} & Housing Pattern & Thatched & 71 & 59.2 & \multirow[b]{3}{*}{1.6} & \multirow[b]{3}{*}{0.79} \\
\hline & & Semi pucca & 26 & 21.7 & & \\
\hline & & Pucca & 23 & 19.2 & & \\
\hline \multirow{4}{*}{5.} & Land Holding & Marginal & 20 & 16.7 & \multirow[b]{4}{*}{2.38} & \multirow[b]{4}{*}{0.92} \\
\hline & & Small & 51 & 42.5 & & \\
\hline & & Medium & 32 & 26.7 & & \\
\hline & & Large & 17 & 14.2 & & \\
\hline \multirow{3}{*}{6.} & Occupation & Solely vegetable cultivation & 100 & 83.3 & \multirow[b]{3}{*}{1.21} & \multirow[b]{3}{*}{0.52} \\
\hline & & Vegetable and other crops & 14 & 11.7 & & \\
\hline & & Vegetable cultivation and other subsidiary occupations & 6 & 5 & & \\
\hline \multirow{3}{*}{7.} & Farming Experience & $<10$ years & 35 & 29.2 & \multirow[b]{3}{*}{1.94} & \multirow[b]{3}{*}{0.72} \\
\hline & & $10-20$ years & 57 & 47.5 & & \\
\hline & & $>20$ years & 28 & 23.3 & & \\
\hline \multirow{3}{*}{8.} & Annual Income & Low $(<50,000)$ & 34 & 28.3 & \multirow[b]{3}{*}{1.99} & \multirow[b]{3}{*}{0.75} \\
\hline & & Medium $(50,000-1,00,000)$ & 53 & 44.2 & & \\
\hline & & High $(>1,00,000)$ & 33 & 27.5 & & \\
\hline \multirow{3}{*}{9.} & Extension participation & Low $(<8.98)$ & 18 & 15 & & \\
\hline & & Medium (8.98- 17.4) & 81 & 67.5 & & \\
\hline & & High $(>17.4)$ & 21 & 17.5 & 13.19 & 4.21 \\
\hline & Risk Orientation & Low $(<11.12)$ & 41 & 34.17 & & \\
\hline 10. & & Medium (11.12-13.92) & 52 & 43.33 & & \\
\hline & & $\operatorname{High}(>13.92)$ & 27 & 22.5 & 12.52 & 1.40 \\
\hline & Innovativeness in vegetable production & Low $(<11.42)$ & 27 & 22.5 & & \\
\hline 11 & & Medium (11.42- 13.32) & 85 & 70.83 & & \\
\hline & & High $(>13.32)$ & 8 & 6.67 & 12.4 & 0.98 \\
\hline
\end{tabular}

It was from evident from Table 1 that majority (59.1\%) of the vegetable growers belonged to the category of the middleaged group, followed by old age group (21.7\%) and only a few $(19.2 \%)$ were in the young age group category. The data revealed that, majority $(32.5 \%)$ belonged to primary school category followed by illiterate $(23.3 \%)$, only able to read and write $(17.5 \%)$, middle school (11.7\%), high school $(9.2 \%)$ and only a few $(5.8 \%)$ completed their education up to college and above level. The data revealed that the majority of the vegetable growers $(61.7 \%)$ belonged to joint family while the rest $(38.3 \%)$ belonged to the nuclear family. Hence, the dominance of joint family system is there. It was clear that majority of respondents possessed a thatched type of house (59.2\%) followed by semi pucca $(21.7 \%)$, and (19.2\%) had a pucca type of house.

It was also evident from the above table that $42.5 \%$ of the farmer belongs to small land holding category, followed by (26.7\%) were medium land holding category, (16.7\%) were marginal land holding category and $(14.2 \%)$ were large land holding category. It was clear that out of the total respondents, majority $(83.3 \%)$ respondents were involved in solely vegetable cultivation along followed by $11.7 \%$ involved in 
vegetable and other crops and the remaining (5.0\%) were involved in vegetable cultivation along with other subsidiary occupations. It was evident that the majority of farmers (47.5\%) had a medium level of farming experience followed by low (29.2\%) and high (23.3\%) level of farming experience. The data regarding mean score and standard deviation of experience in vegetable cultivation is also presented above. The mean score of experience in vegetable cultivation was 1.94 and S.D. was 0.72 . The results showed that more number of respondents $(44.2 \%)$ belonged to medium annual income category, followed by $28.3 \%$ of them belonged to low annual income category. While, $27.2 \%$ of them, belonged to high annual income category. The table also presents the data regarding mean score and S.D of annual income. The mean score of annual income was 1.99 and S.D. was 0.75 . The perusal of data indicates that 67.5 percent of respondents had medium level of extension contact. It was evident that $44.33 \%$ of the respondents had a medium risk-bearing ability and followed by (34.17\%) of low risk bearing ability and (22.5\%) of high risk bearing ability. It was revealed that $70.83 \%$ of the respondents had a medium level of innovativeness category followed by $22.5 \%$ and $6.67 \%$ belonged to low and high innovativeness category, respectively. The majority of the respondents belonged to the medium innovativeness category. This might be due to higher extension participation and media exposure. The findings were to most extent confirmative with the findings of Boruah, R. et al. (2015) and Gamit, P. S. (2016) et al.

\section{Information source consultancy pattern of vegetable growers}

Table 2: Analysis of Information source consultancy pattern of the vegetable growers

\begin{tabular}{|c|c|c|c|c|c|c|c|c|c|}
\hline \multirow{3}{*}{$\begin{array}{c}\text { Sl. No } \\
\text { A. }\end{array}$} & \multirow{3}{*}{$\begin{array}{c}\text { Sources of information } \\
\text { Informal sources }\end{array}$} & \multicolumn{6}{|c|}{ Extension participation } & \multirow{3}{*}{ Mean score } & \multirow{3}{*}{ Rank } \\
\hline & & \multicolumn{2}{|c|}{ Regular } & \multicolumn{2}{|c|}{ Occasional } & \multicolumn{2}{|c|}{ never } & & \\
\hline & & $\mathbf{F}$ & $\%$ & $\mathbf{F}$ & $\%$ & $\mathbf{F}$ & $\%$ & & \\
\hline 1 & Relatives & 59 & 49.2 & 43 & 35.8 & 18 & 15.0 & 2.341 & I \\
\hline 2 & neighbours & 35 & 29.2 & 73 & 60.8 & 12 & 10.0 & 2.191 & II \\
\hline 3 & Progressive farmer & 31 & 25.8 & 24 & 20.0 & 65 & 54.2 & 1.716 & III \\
\hline 4 & Local leaders & 17 & 14.2 & 33 & 27.5 & 70 & 58.3 & 1.558 & $\mathrm{~V}$ \\
\hline 5 & NGO workers & 12 & 10.0 & 45 & 37.5 & 63 & 52.5 & 1.575 & IV \\
\hline B. & \multicolumn{9}{|c|}{ Formal sources } \\
\hline 1 & KrishakMitra & 31 & 25.8 & 65 & 54.2 & 24 & 20.0 & 2.058 & II \\
\hline 2 & VLW/BTM/ATM & 23 & 19.2 & 25 & 20.8 & 72 & 60.0 & 1.575 & IV \\
\hline 3 & Block agriculture officer & 8 & 6.7 & 42 & 35.0 & 70 & 58.3 & 1.483 & $\mathrm{~V}$ \\
\hline 4 & District agriculture officer & 3 & 17.5 & 10 & 8.3 & 107 & 89.17 & 1.133 & VII \\
\hline 5 & SMS & 25 & 20.8 & 20 & 16.7 & 75 & 62.5 & 1.583 & III \\
\hline 6 & Input agencies & 49 & 40.8 & 55 & 45.8 & 16 & 13.3 & 2.275 & $\mathrm{I}$ \\
\hline 7 & Birsa agricultural university scientists & 0 & 0 & 27 & 22.5 & 93 & 77.5 & 1.225 & VI \\
\hline 8 & Other sources & 2 & 1.7 & 16 & 13.3 & 102 & 85.0 & 1.166 & VII \\
\hline C. & \multicolumn{9}{|c|}{ Mass media sources } \\
\hline 1 & Newspaper & 65 & 54.2 & 43 & 35.8 & 12 & 10.0 & 2.441 & II \\
\hline 2 & Farm literature & 54 & 45.0 & 49 & 40.8 & 17 & 14.2 & 2.308 & III \\
\hline 3 & Agriculture film show & 0 & 0 & 95 & 79.2 & 25 & 20.8 & 1.791 & VI \\
\hline 4 & Agricultural meetings/ Training & 23 & 19.2 & 60 & 50.0 & 37 & 30.8 & 1.883 & $\mathrm{~V}$ \\
\hline 5 & Farmers fairs/ Exhibition & 27 & 22.5 & 69 & 57.5 & 24 & 20.0 & 2.025 & IV \\
\hline 6 & Radio & 2 & 1.7 & 29 & 24.2 & 89 & 74.2 & 1.275 & VIII \\
\hline 7 & Television & 90 & 75.0 & 14 & 11.7 & 16 & 13.3 & 2.616 & $\mathrm{I}$ \\
\hline 8 & Social media & 39 & 32.5 & 14 & 11.7 & 67 & 55.8 & 1.766 & VII \\
\hline
\end{tabular}

Table 2 showed that in case of informal sources of information relatives occupied the highest mean score 2.341 and ranked $1^{\text {st }}$, followed by neighbours, progressive farmers, NGO workers and local leaders with mean scores of 2.191, $1.716,1.575,1.558$ and ranked $2^{\text {nd }}, 3^{\text {rd }}, 4^{\text {th }}$, and $5^{\text {th }}$ respectively in order of preference. The relatives got the highest preference by the respondents, because these sources are easily available to the farmers at the local level and they can easily gain information and share their ideas with them than any outsiders.

From the above table it is evident that in case of formal sources input agencies occupied the highest mean score 2.275 and ranked $1^{\text {st }}$, followed by Krishak Mitra, SMS, VLW/BTM/ATM, Block agriculture officer, BAU scientists, other sources and District agriculture officers with mean scores of $2.058,1.583,1.575,1.483,1.225,1.166,1.133$ and ranked $2^{\text {nd }}, 3^{\text {rd }}, 4^{\text {th }}, 5^{\text {th }}, 6^{\text {th }}, 7^{\text {th }}$, and $8^{\text {th }}$ respectively in order of their preference. The input agencies served as the most important source of information, the reason might be that these sources are easily accessible to the farmers and it is preferred by them to share their ideas with input dealers and get information regarding various issues than any other other sources.

From the above table it was clear that in case of mass media sources T.V occupied the highest mean score 2.616 and ranked $1^{\text {st }}$, followed by newspapers, farm literatures (posters, leaflets, etc.), farmers fairs/exhibitions, agricultural meetings/trainings, agricultural film show, social media and radio with mean scores of $2.441,2.308,2.025,1.883,1.791$, $1.766,1.275$ and ranked $2^{\text {nd }}, 3^{\text {rd }}, 4^{\text {th }}, 5^{\text {th }}, 6^{\text {th }}, 7^{\text {th }}$, and $8^{\text {th }}$ respectively in order of their preferences. The television was the most preferred as their information source might be due to expertise of interviewed personnel, less cost, ease of communication and agriculture programmes for all TV channels 
Table 3: Distribution of vegetable growers according to their overall information source consultancy pattern

\begin{tabular}{|c|c|c|c|c|c|}
\hline Sl. No & Category & Frequency & Percentage & Mean & S.D \\
\hline 1. & Low $(<31)$ & 12 & 10 & & \\
\cline { 1 - 4 } 2. & Medium $(31-45.62)$ & 85 & 70.83 & & \\
\cline { 1 - 4 } 3. & High $(>45.62)$ & 23 & 19.17 & 38.31 & 7.31 \\
\hline
\end{tabular}

It is clear from table 3 that the majority 70.83 percent of the respondents showed a medium level of information source consultancy pattern followed by 19.17 percent respondents having high level of information source consultancy and only 10 percent of respondents showed a low level of information source consultancy pattern.

\section{Conclusion}

The study was carried out to indicated that majority of the respondents belonged to the middle age group (59.1\%), had received primary school level education (32.5\%), having a small size of land holding, having vegetable cultivation as their main occupation, having medium annual family income, with a medium degree of risk orientation and a medium level of innovativeness. It was clear that in case of informal sources of information relatives occupied the highest mean score 2.341 and ranked $1^{\text {st }}$, in case of formal sources input agencies occupied the highest mean score 2.275 and ranked $1^{\text {st }}$ and in case of mass media sources T.V occupied the highest mean score 2.616 and ranked $1^{\text {st }}$ whereas in case of overall information source consultancy pattern the majority 70.83 percent of the respondents showed a medium level of information source consultancy pattern.

\section{References}

1. Agarwal NL, Saini TC. Vegetable marketing - A study of Jaipur market (Rajasthan). Indian J Agril. Mktg. 1995; 9(1):36-43.

2. Balusu KB. Marketing behavior of vegetable growers in Ranga Reddy district of Andhra Pradesh, Thesis, Acharya N.G. Ranga Agricultural University, Hyderabad, Hyderabad, 2014.

3. Barik J. A study on the entrepreneurial behavior of vegetable grower of Cuttuck district, M.Sc. (Ag.) Thesis, Orissa University of Agriculture and Technology, 2013.

4. MadhuShekar BR. Study on Marketing Behaviour of Chilli Growers In Guntur District Of Andhra Pradesh, M.Sc. (Ag.) Thesis, Acharya N.G. Ranga Agricultural University, Hyderabad, 2009.

5. Mohapatra SC. Production and marketing of onion in Bolangir district of Orissa. Indian J Agric. Markt. 1999; 13(1):40-43.

6. Saravana Kumar R. A study on management of mango gardens by farmers in Krishnagiritaluk of Dharmapuri district, Tamil Nadu. M. Sc. (Agri.) Thesis, Univ. Agric. Sci., Dharwad (India), 1996.

7. Sayonalla KR. A study of impact of Jankidevi Bajaj Gram Vikas Sanstha on the beneficieary farmers of Maval and Khedtalukas of Pune district. M.Sc. (Agri) Thesis (unpublished) submitted to M.P.K.V., Rahuri (M.S), 2002. 